\title{
The Challenges of E-Learning Implementation During the Covid-19 Pandemic in Senior High School
}

\author{
Fitra Delita \\ Department of Geography Education, Faculty of Social Sciences, Universitas Negeri Medan \\ "Correspondence: delitafitra@gmail.com
}

Received: 28 October 2021; Accepted: 7 December 2021; Published: 27 December 2021

\begin{abstract}
The Covid-19 pandemic has brought changes in various fields of life, including education. The purpose of this study was to describe the challenges faced by teachers and students in e-learning in the Covid19 pandemic. This study uses a qualitative approach through data collection using an online questionnaire with Google form and structure interview by phone. Respondents consisted of 163 geography teachers and 104 students at the high school level in North Sumatra Province. This data is then analyzed descriptively in the form of scores and percentages. The result showed that the challenges faced by teachers were especially expertise, preparation for learning, access to e-learning, management of learning in the e-learning platform, supporting facilities, and time effectiveness in e-learning. While the challenges faced by students include understanding the material, access to the learning process, discipline in online learning, learning support facilities for e-learning, and the conditions of the learning environment.
\end{abstract}

Keywords: the challenges, e-learning, teacher's perspectives, student's perspectives

Abstrak: Pandemi Covid-19 membawa perubahan pada berbagai bidang kehidupan termasuk bidang pendidikan. Tujuan penelitian ini adalah untuk mendeskripsikan tantangan yang dihadapi guru dan siswa pada e-learning di masa pandemi. Penelitian ini menggunakan pendekatan kualitatif melalui pengumpulan data dengan kuesioner online menggunakan Google form dan wawancara terstruktur melalui telepon. Responden terdiri atas 163 guru geografi dan 104 siswa Sekolah Menengah Atas di Provinsi Sumatera Utara. Data dianalisis secara deskriptif dalam bentuk skor dan persentase. Hasil penelitian menunjukkan bahwa tantangan yang dihadapi guru antara lain keahlian, persiapan pembelajaran, akses e-learning, pengelolaan pembelajaran dalam platform e-learning, fasilitas pendukung dan efektifitas waktu. Sedangkan tantangan yang dihadapi siswa meliputi pemahaman terhadap materi, akses e-learning, disiplin dalam e-learning, fasilitas pendukung dan kondisi lingkungan pembelajaran.

Kata kunci: tantangan, e-learning, perspektif guru, persfektif siswa

\section{INTRODUCTION}

E-learning is increasingly popular in Indonesia. During the Covid-19 pandemic, face-to-face learning was dropped to prevent an outbreak. The government and leaders of educational institutions need to establish safe methods so that learning can continue during a pandemic (Reimers et al., 2020). ICT-based learning such as e-learning is a necessity so that learning continues as long as school buildings are closed, as has become a common government policy in various countries (United Nations, 2020). E-learning is the main alternative for implementing learning, starting from kindergarten to college levels. This policy is set by the government through the Indonesian Ministry of Education and Culture. Face-to-face learning activities in class shift to virtual space through online learning (Ali, 2020). This is of course a challenge for education delivery. This challenge is especially 
felt among teachers (Giuffrida et al., 2020; Garza, 2020) and students (Adnan \& Anwar, 2020; Shikongo, 2020).

E-learning has its own advantages and disadvantages. The advantages of E-learning include: providing flexible distance learning opportunities for students (Zhang, 2006), economic benefits due to lower costs (Bartley \& Golek, 2004), allows collaboration and partnerships of students from various regions of origin, both at local, national and international levels (Lu et al, 2004), facilitates the management of teaching materials and the process of updating learning is faster and easier (Gamdi \& Samarji, 2016), in addition to studying material online learning can also improve students' writing and computer skills (Weiner, 2003), students can become more interactive, responsive, and share knowledge so as to enrich learning experiences and resources (Dhull \& Sakshi, 2017). For teachers, the main advantage in e-learning is the ease of sharing teaching materials in various formats such as word, pdf, video, audio and others, easy access to materials in the form of material links, web or directly distributed to WA groups, use of e-learning platforms in the form of LMS that facilitates documentation of every learning activity such as curriculum setting, attendance monitoring, assignments, learning deadlines, sending private or group messages, evaluations, and even interactions with parents to report student learning achievements.

The limitations in e-learning that may often occur include the need for careful planning, learning that cannot be accessed by students who do not have supporting equipment such as computers (Selvaraj, 2021; Berutu et al., 2019), Android devices, or unstable internet connections (Zhang, 2006), limited ability and experience, creativity and expertise of teachers in e-learning management, including pedagogic abilities (Liguori \& Winkler, 2020), crisis management (Bartley \& Golek, 2004), difficulties in ensuring participation or controlling student activities, because students may open other websites or play games during the learning process (Delita et al., 2019). Obstacles to online learning on the dimensions of teachers include lack of ICT expertise, lack of experience and knowledge about online learning, teachers who find it difficult to adapt to change and development of online learning programs that require a lot of time and lack of motivation (Gamdi \& Samarji, 2016; Moscinska \& Rutkowski, 2011; Sojanah et al., 2021).

The main objective of this study was to describe the challenges teachers and students encountered in implementing e-learning during the Covid-19 pandemic. This problem is very important to study because online learning is not only a trend that occurs during a pandemic, but is also a demand in the 21st century education sector in the industrial era 4.0. This study is useful for various elements of education, including: (1) for teachers: as the spearhead of teaching and learning activities; (2) for students: as subjects and objects of education; (3) for parents: as a control function of children's education; (4) for academics, education practitioners, educational institutions, and the government: as material for consideration in education policy-making.

\section{METHOD}

This study uses a qualitative method that describes the facts in the subject of Geography elearning in Senior High Schools throughout North Sumatra Province. Respondents in the study included Geography teachers who are members of an association called the North Sumatra Geography Teacher Associate. The number of respondents was 104 students and 163 teachers (Table 1).

Table 1. Description of Research Participants

\begin{tabular}{llcc}
\hline Participants & Gender & Frequency & Percentage \\
\hline \multirow{3}{*}{ Students } & Male & 41 & 39.42 \\
& Female & 63 & 60.58 \\
& Total & 104 & 100 \\
\hline \multirow{3}{*}{ Teachers } & Male & 69 & 42.33 \\
& Female & 94 & 57.67 \\
& Total & 163 & 100 \\
\hline$---o$
\end{tabular}


All participants did not have sufficient experience in online learning, both teachers and students. The main indicators of challenges for teachers in this study include online learning management skills, access to online learning, use of online learning platforms, availability of facilities and time effectiveness in online learning. While the indicators of student challenges include mastery of the material, internet access, discipline in online learning, supporting facilities and environmental conditions during online learning.

The data were collected through an online questionnaire using google form and structured interviews by telephone. Measurement of instrument validity was carried out with construct validity by three experts who are experienced in educational research. The instruments are declared valid if the items are in accordance with the research objectives on each indicator. The questionnaires were distributed to the teacher's whatsapp group and the teachers selected several students in their class to fill out the student questionnaires. Then 17 teachers and 15 students were randomly selected to be interviewed to obtain more in-depth information regarding the challenges encountered in online learning.

Data analysis was carried out by descriptive statistics and qualitative analysis. Descriptive statistics were used to analyze the questionnaire data presented in the form of frequency distribution tables and graphs. Meanwhile, interview data were analyzed qualitatively and presented in narrative form. Qualitative analysis was carried out through the stages of data reduction, data categorization, data presentation and drawing conclusions.

\section{RESULT AND DISCUSSION}

Results

Face-to-face learning has suddenly shifted to online learning during the COVID-19 pandemic. This online learning system has been in effect since early March 2020 at all levels of education. Teachers and students experienced various challenges in the early days of online learning from home.

\section{The challenges of e-learning from a teacher's perspective}

The challenges of e-learning from the teacher's perspective in this study consisted of expertise in managing e-learning, access to e-learning, the use of various e-learning platforms, supporting facilities and the effectiveness of e-learning time. The severity of these challenges can be seen in the Figure 1.

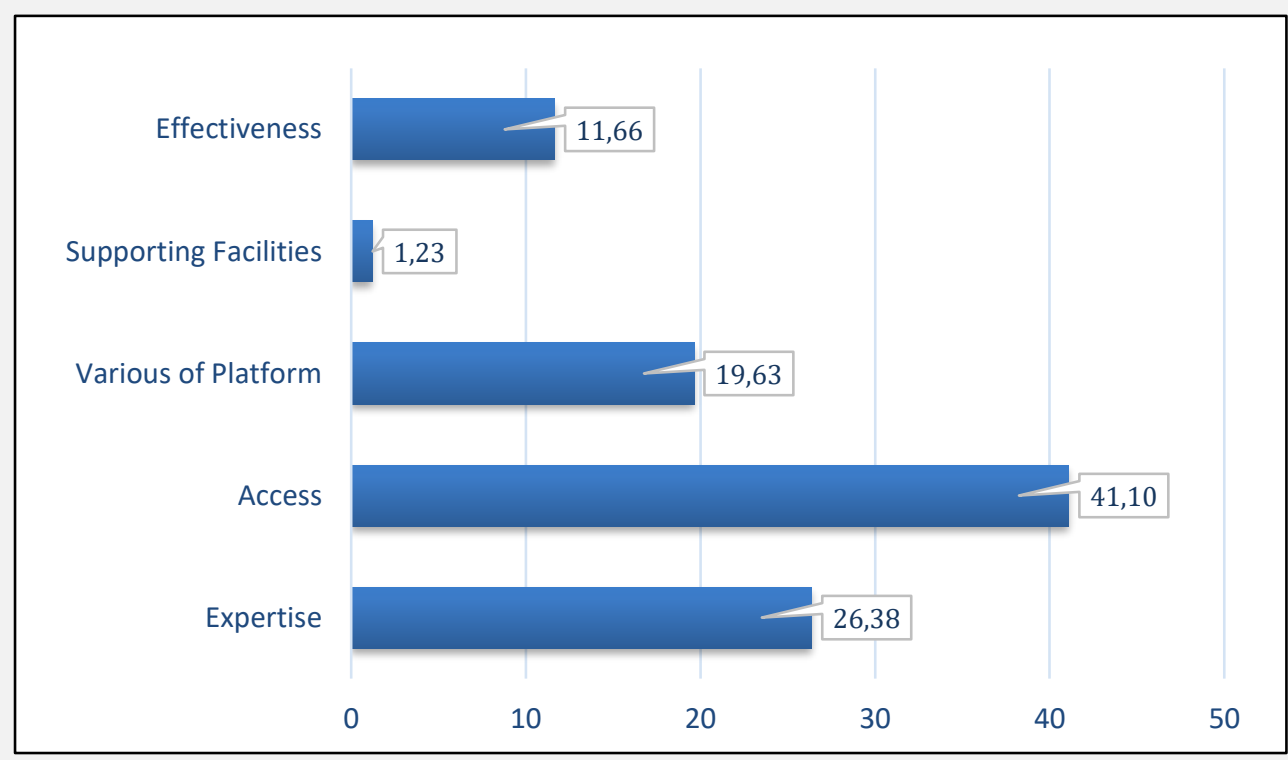

Figure 1. Challenges of E-Learning Faced by Teachers 
Figure 1 shows that the biggest challenge faced by teachers is access to e-learning (41.10\%). This is related to the internet network which is often unstable when online teaching and learning is taking place. The next challenge is on the aspect of teacher expertise in managing online learning $(26.38 \%)$. This aspect includes planning, implementation and assessment. Another challenge is the difficulty in using various online learning platforms (19.63\%) and the effectiveness of online learning, especially in terms of time duration (11.66\%). Another small challenge in online learning is supporting facilities (1.23\%), namely the hardware used in the learning process such as computers, laptops, and Android phones. Generally, all teachers have these devices.

The forms of online learning activities carried out by teachers are quite diverse, such as uploading materials, presentations, discussions, virtual meetings, assignments and others. This can be seen in Figure 2.

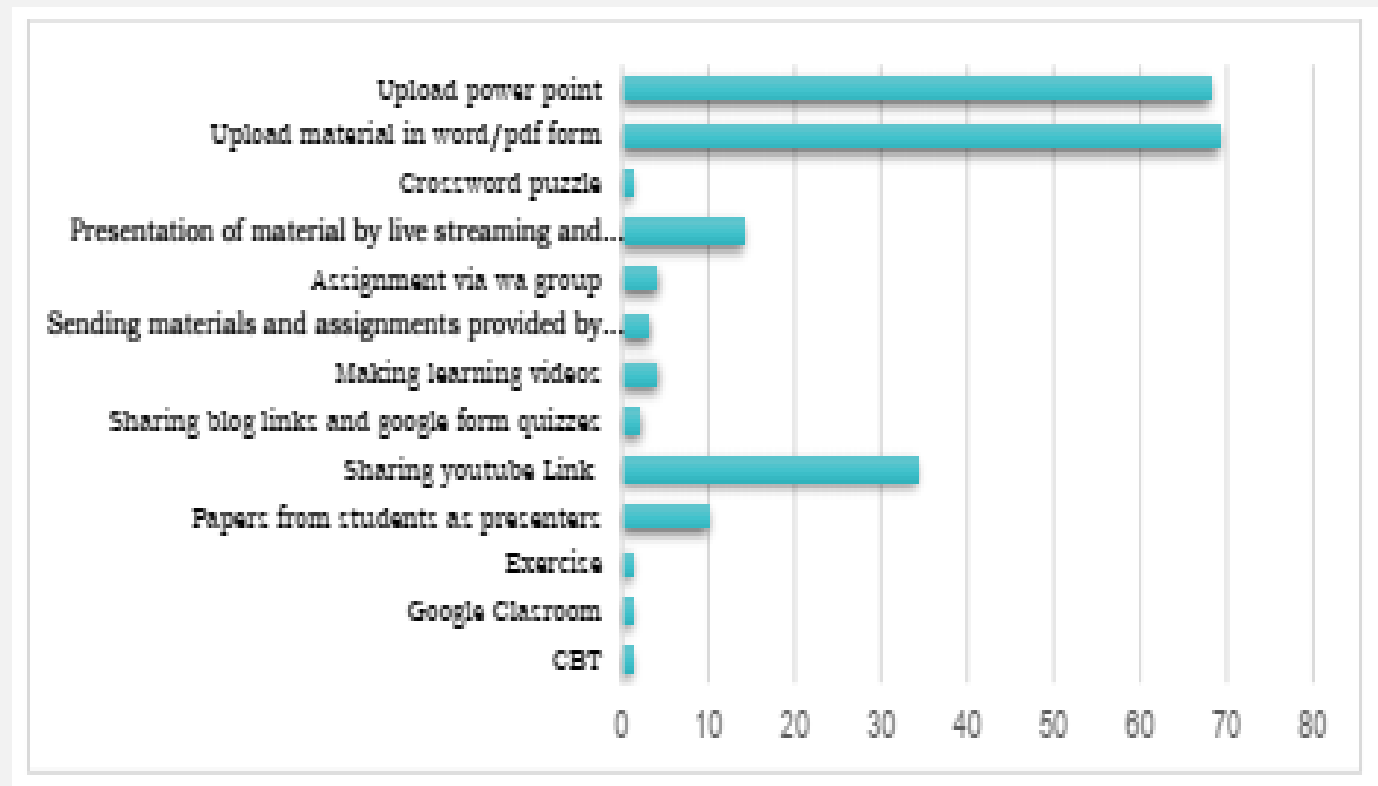

Figure 2. Learning Activities During Online Learning

\section{The challenges of e-learning from a student's perspective}

Online learning challenges faced by students include understanding material, internet access in the learning process, discipline in online learning, e-learning supporting learning facilities and learning environment conditions. The magnitude of this challenge can be seen in Figure 3 below.

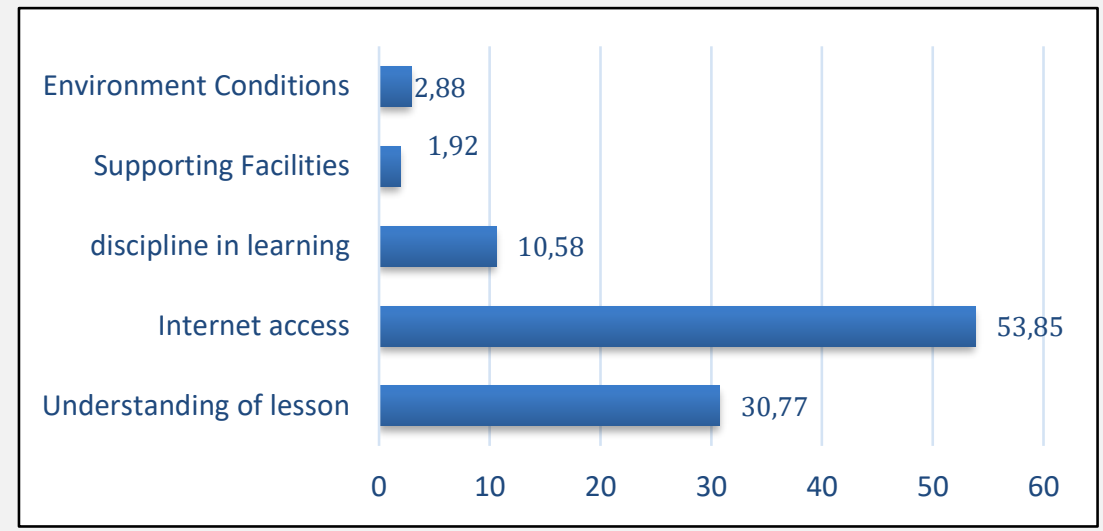

Figure 3. Challenges of E-Learning Faced by Students 
Figure 3 shows that the biggest challenge faced by students is internet access during the elearning process $(53.85 \%)$. The internet network during the learning process is often disrupted due to bad weather, off-grid location of the house, and insufficient data packages. The next challenge is mastery of the material (30.77\%). Online learning has limited time. This limits the interaction in learning which includes the interaction of students with teachers, interactions among students during learning. This limitation causes students to understand less about the material. Another challenge is discipline (10.58\%) and environmental conditions in online learning $(2.88 \%)$. Often students cannot focus and even do other activities during learning. Then various disturbances around the house during the learning process. Meanwhile, the smallest challenge is supporting facilities (1.92\%). Although most students do not have computers or laptops, students can access online learning through smartphone devices.

\section{Discussion}

The sudden change from a face-to-face learning system to online learning poses challenges in the delivery of education in Indonesia, including at the secondary education level. The challenges of e-learning at the secondary education level can be viewed from the perspective of teachers and students. Internet access is a major challenge for teachers and students. The lack of access to technology and the availability of internet access are obstacles to participating in e-learning for students in rural areas and those from underprivileged families (Britt, 2006; Kaur, 2020; Liguori \& Winkler, 2020). In addition, poor internet networks are also due to weather disturbances such as rain and poor signals in certain locations. The next challenge for teachers is expertise in managing online learning, which includes lesson planning, learning implementation and learning evaluation. Included in this section is the use of digital media and learning resources. Online learning is an electronic learning method supported by internet, the use of digital platforms and devices such as computers, laptops, smartphones and their likes (Müller \& Faltin, 2011; Nussbaumer et al., 2015). Online learning is thus also supported by electronic learning resources (Berutu et al., 2019). So, the ability of teachers to manage online learning is very important. The lack of teacher experience is related to the lack of expertise in managing online learning both planning, implementation and assessment. Even technical aspect such as the use of various platforms and media. Of course, this is related to the teacher's pedagogy (Diningrat et al., 2020).

Time effectiveness is also a challenge for teachers in the online learning process. In face-toface learning the teacher can maximize the time allocation because the teacher and students are in the classroom. While in online learning the teacher and each student are in different places with far apart locations. Learning takes place by utilizing technology that allows interaction between teachers and students both in virtual meeting/conference rooms or in the form of LMS through discussion forums, chat and others. This learning activity is of course very dependent on the stability of the internet network. If there is internet interference, learning will be disrupted. Often online learning takes longer because the teacher waits for all students to join the lesson, especially during virtual meetings via Zoom or Google Meet. Technical things like this need to be circumvented by teachers by utilizing other technologies for communication such as WhatsApp groups. Likewise, when the teacher gives practice, students need more time. Even time is used when reading and replying to messages in the group. Not only that, the preparation of online learning also takes the teacher's time. Lesson materials need to be prepared before starting the lesson (Turnbull et al., 2019).

As for students, the second biggest challenge after internet access is understanding the material. Online learning limits student and teacher interactions, so that teacher services in the learning process are limited (Toquero, 2020; Pace et al., 2020). Students are required to learn to be more independent and the success of their studies is very much determined by this independence. Students who also have limited internet networks, inadequate learning resources and low learning motivation of course, have low achievement. E-learning will be effective in developed countries which are sophisticated technology (Basilaia \& Kvavadze, 2020).

Discipline during online learning is also a challenge for students. Often students are tempted to do other activities during learning. For example, while opening social media that is not related 
to learning. There are also those who play games, listen to music and watch television while taking lessons. So parental supervision is very important when learning from home. Environmental conditions during learning are also part of the challenges faced by students in online learning. Most of the students are at home while learning. Distractions can occur in the form of noise that reduces concentration. In addition, the location of students also determines the smoothness of the internet network so this condition needs to be considered.

\section{CONCLUSION}

There were various challenges faced by teachers and students in the online learning process during the Covid-19 pandemic, the meeting point of which was the difficulty of internet access. Therefore, this challenge can be overcome by increasing internet access so that the learning process can take place optimally. Through the Ministry of Education and Culture, the Government can allocate funds to expand the internet network to remote areas as well as provide internet quota subsidies for online learning. Meanwhile, other challenges related to teacher ability can be resolved by improving the quality of human resources through training, workshops, and self-taught learning. Likewise, for students, their learning success needs to be ensured through increased motivation, persistence, self-direction and independence.

\section{ACKNOWLEDGEMENT}

We are grateful to the Research and Community Service Institute Universitas Negeri Medan for funding this study. The authors also thank the Geography Teachers and students who have contributed to this study.

\section{REFERENCES}

Adnan, M \& Anwar, K. (2020). Online Learning amid the COVID-19 Pandemic: Students' Perspectives. Journal of Pedagogical Sociology and Psychology, 2(1), 45-51. https://doi.org/10.33902/JPSP.2020261309

Ali, W. (2020). Online and Remote Learning in Higher Education Institutes: A Necessity in light of COVID-19 Pandemic. Higher Education Studies, 10(3), 16-25. https://doi.org/10.5539/hes.v10n3p16

Bartley, S. J., \& Golek, J. H. (2004). Evaluating the Cost Effectiveness of Online and Face-to-Face Instruction. Educational Technology and Society, 7(4), 167-175.

Basilaia, G., \& Kvavadze, D. (2020). Transition to Online Education in Schools During a SARS-CoV2 Coronavirus (COVID-19) Pandemic in Georgia. Pedagogical Research, 5(4), 1-9.

Berutu, N., Delita, F., Astuti, A.J.D., Novira, N \& Wirda, M.A. (2019). The Strategy To Strengthen Information Literacy Based On Library and Digital Resources. https://dx.doi.org/10.2991/icssis18.2019.28

Britt, R. (2006). Online Education: A Survey of Faculty and Students. Radiologic Technology, 77(3), 183-190.

Delita, F., Arif, M., Rosni, R., Sitompul, M. \& Rohani, R. (2019). Improving The Quality of Learning Through Assignment System. Journal of Physics: Conference Series. https://doi.org/10.1088/1742-6596/1175/1/012154

Diningrat, S.W.M., Nindya, M.A \& Salwa, S. (2020). Emergency Online Teaching: Early Childhood Lectures' Perception of Barrier and Pedagogical Competency. Cakrawala Pendidikan, 39(3). https://doi.org/10.21831/cp.v39i3.32304 
Dhull, I. \& Sakshi, M. S. (2017). Online Learning. International Education \& Research Journal, 3(8), 32-34.

Gamdi, M. A. A. \& Samarji, A. (2016). Perceived Barriers towards e-Learning by Faculty Members at a Recently Established University in Saudi Arabia. International Journal of Information and Education Technology, 6(1), 23-28. https://doi.org/10.7763/IJIET.2016.V6.652

Garza , A. (2020). Universidad Autónoma de NL suspende clases por Covid-19. [Autonomous Univeristy of NL suspends classes because of Covid-19]. Excélsior (in Spanish). 67.

Giuffrida. A, Tondo, L. \& Beaumont, P. (2020). Italy Orders Closure of All Schools And Universities Due to Coronavirus. The Guardian. ISSN 0261-3077. Retrieved 2020-03-15.

Kaur, G. (2020). Digital Life: Boon or bane in teaching sector on COVID-19. CLIO an Annual Interdisciplinary Journal of History, 6(6), 416-427.

Liguori, E., \& Winkler, C. (2020). From Offline to Online: Challenges and Opportunities for Entrepreneurship Education Following the COVID-19 Pandemic. Entrepreneurship Education and Pedagogy. Vol. 3(4) 346-351. https://doi.org/10.1177/2515127420916738

Lu, W., Diggs, L., \& Wedman, J. (2004). Building Cross Cultural Partnerships Through the Internet. Proceedings of World Conference on Educational Multimedia, Hypermedia and Telecommunications, pp. 4782-4786.

Müller, N., \& Faltin, N. (2011). IT-Support for Self-Regulated Learning and Reflection on the Learning Process. ACM International Conference Proceeding Series. https://doi.org/10.1145/2024288.2024299.

Moscinska, K. \& Rutkowski, J. (2011). Barriers to Introduction of E-Learning: A Case Study. IEEE Global Engineering Education Conference (EDUCON). pp. 460-465. https://doi.org/10.1109/EDUCON.2011.5773176

Nussbaumer, A., Dahn, I., Kroop, S., Mikroyannidis, A., \& Albert, D. (2015). Supporting SelfRegulated Learning In Responsive Open Learning Environments. Journal of Educational Psychology, 62 (5), pages 17-48. https://doi.org/10.1007/978-3-319-02399-1_2

Pace, C., Pettit, S. K., \& Barker, K. S. (2020). Best practices in middle level quaranteaching: Strategies, tips and resources amidst COVID-19. Becoming: Journal of the Georgia Association for Middle Level Education, 31(1), 2-13. https://doi.org/10.20429/becoming.2020.310102

Reimers, F., Schleicher, A., Saavedra, J., \& Tuominen, S. (2020). Supporting the continuation of teaching and learning during the COVID-19 Pandemic. Oecd, 1(1), 1-38.

Selvaraj, A., Radhin, V., Nithin, K. A., Benson, N., \& Mathew, A. J. (2021). Effect of Pandemic-Based Online Education on Teaching and Learning System. International Journal of Educational Development, 85, 102444. https://doi.org/10.1016/j.ijedudev.2021.102444

Shikongo, A. ( 2020). Namibia Battles Coronavirus. The Namibian. p. 1.

Sojanah, J., Suwatno, K. \& Machmud, A. (2021). Factors Affecting Teachers' Technological Pedagogical And Content Knowledge (A Survey On Economics Teacher Knowledge). Cakrawala Pendidikan, 40(1). https://doi.org/10.21831/cp.v40i1.31035 
Toquero, C. M. (2020). Challenges and Opportunities for Higher Education amid the COVID-19 Pandemic: The Philippine Context. Pedagogical Research. 5(4). https://doi.org/10.29333/pr/7947

Turnbull, D., Chugh, R., \& Luck, J. (2019) Learning Management Systems: An Overview. Encyclopedia of Education and Information Technologies, 1-7. https://doi.org/10.1007/978-3319-60013-0_248-1

United Nations. (2020). Policy Brief: Education During COVID-19 and Beyond.

Weiner, C. (2003). Key Ingredients to Online Learning: Adolescent Students Study in Cyberspace The Nature of The Study. International Journal on E-Learning, 2(3), 44-50.

Zhang, L. (2006). Effectively Incorporating Instructional Media into Web-Based Information Literacy. The Electronic Library, 24(3),294-30.

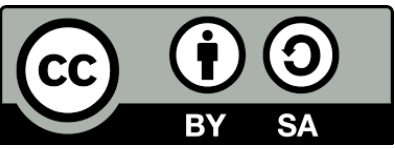

Copyright (c) 2021 by the authors. This work is licensed under a Creative Commons Attribution-ShareAlike 4.0 International License. 